\title{
MEDICINES FOR IMMUNOLOGICAL PROPHYLAXIS AGAINST INFECTIOUS DISEASES AND POULTRY EIMERIOSIS AT THE DOMESTIC PHARMACEUTICAL MARKET
}

\section{Franchuk-Kryva Liubov ${ }^{1}$}

DOI: https://doi.org/10.30525/978-9934-571-89-3_90

The number of poultry head in Ukraine was amounted to 210.8 million according to the data up to 01.01.2019 and 118 million from these heads were concentrated on poultry farms [3]. As an intensive industry, poultry farming is aimed to increase production volumes continuously, at the same time to reduce the cost of poultry's maintenance and feeding. Under such conditions, the birds are affected by a significant number of stress factors that provoke the decrease of body's resistance. Similar trends increase the percentage of poultry disease. 35-70\% of losses in poultry farming were caused by invasive diseases, among which the most unprofitable is eimeriosis. Each year the losses caused by eimeriosis in the world are about $500 \$$ million [8, p. 7].

Chemotherapy is still considered to be the most effective and economically proved measure to prevent and control eimerosis. The negative aspect of chemoprophylaxis of eimeriosis is its high embryotoxicity and a negative effect on hens' reproductive system [4, p. 126; 5, p. 35]. In addition, long-termed unlimited use of synthetic agents contributes to the development of resistance to all types of eimeries. The degree of resistance to certain medicines during chemotherapy is so great that new approaches for treatment must be found $[1$, p. 14;2, p. 27; 9].

A prospective direction in the fight against eimeriosis is immunological prophylaxis [6, p. 13; 8, p. 35].

There are about 20 vaccines against hen eimeriosis in the world today. Vaccines with live pathogens, injection vaccines and vaccines developed on the basis of

${ }^{1}$ Odessa State Agrarian University, Ukraine 
molecular biotechnology (recombinant, DNA vaccine, etc.) have been developed for immunological prophylaxis of poultry eimeriosis [4, p. 126; 6, p. 13; 8, p. 11].

Taking into considerations all above mentioned aspects, the definition and analysis of the spectrum of vaccine available on the pharmaceutical market for the immunological prophylaxis against infectious diseases and poultry eimeirosis is an actual issue.

The purpose of the work was to investigate the market of vaccines medicines for poultry and particular, medicines for poultry immunological prophylaxis registered in Ukraine. The study of the range of immune biological medicines was carried out by analyzing official sources of information [7]. During the study, statistical, comparative and analytical methods of analysis were used.

According to the data on 01.01.2019, 623 immunological products with valid registration certificates were registered at the veterinary pharmaceutical market of Ukraine [7]. The range of vaccines for poultry includes 241 trade names (TN) and it is accounted $38.7 \%$ from the total. $73.9 \%(178 \mathrm{TN})$ vaccines - against certain poultry diseases. Immune biological preparations against certain poultry diseases are mainly vaccines against Newcastle disease $-22.5 \%(40 \mathrm{TN})$, infectious bronchitis $14.6 \%(26 \mathrm{TN})$ and infectious bursal disease $-12.4 \%(22 \mathrm{TN})$. In general, in the market of immune biological medicines there are vaccines against 23 poultry diseases -22 diseases of infectious etiology and 1 - invasive (eimeriosis).

Moreover, $26.1 \%(63 \mathrm{TN})$ of vaccines were complex. Among them there are dualvalued associated vaccines $-52.4 \%(33 \mathrm{TN})$, namely the vaccine against Newcastle disease and infectious bronchitis $-51.5 \%(17 \mathrm{TN})$.

The vaccine for hens is dominated - $96.7 \%(233 \mathrm{TN})$ in the structure of the assortment. The vaccines presented for certain types of poultry (turkeys, ducks, geese, pigeons) make up $3.3 \%(8 \mathrm{TN})$ that is a bit smaller quantities. Totally $85.9 \%$ of vaccines for poultry are of foreign production and only $14.1 \%$ - are produced in Ukraine.

Imported vaccine medicines for poultry are represented by 15 producer countries, the leading position among which is the USA - $47 \mathrm{TN}$, Italy - $37 \mathrm{TN}$, the Netherlands - 35 TN and Spain - 25 TN.

There are some available vaccines of foreign production against eimeria (Canada, USA, United Kingdom, Spain, Australia, Czech Republic) at the pharmaceutical market. Immunization against eimeriosis must be carried out on hens mainly in poultry breeding and commercial poultry farms, especially when birds are kept on the floor.

The volume of vaccines against poultry eimeria at the pharmaceutical market of Ukraine is $5.6 \%(10 \mathrm{TN})$. Among them, the percentage of live virulent vaccines is $30 \%$ (Iттисох-3, Iттисох-5, Iттиисох CII). Immunococcus vaccine (Ceva Animal Health Inc., Canada) includes oocytes with vitamins and vitamins. These vaccines contain from 3 to 5 types of virulent most common oocyst eimeria: E. tenella, E. acervulina, E. maxima, E. brunetti, E necatrix.

It is rational to use vaccine medicines, the species composition of which corresponds to the actual species for the given geographic area. This is due to the fact 
that any vaccine can expand the species composition of the pathogen, which circulates in the poultry factory [5, p. 35].

It is believed that the use of live non-acetone vaccines is accompanied by lesions of the intestinal mucosa of the bird. On the one hand, it is good stimulates the development of active immunity and on the other, it promotes the emergence of necrotic bacterial enteritis, due to the activation of Clostridium perfringens [6, p. 127; 8, p. 11].

At present, the percentage of live attenuated vaccines against bird eimerosis is higher $-70 \%$ and is represented by $\mathrm{TN}$ as Livacox $Q$, ADVENT®, Fortegra, EVALON, Paracox, Paracox-5, Eimeriavax $4 \mathrm{~m}$. These vaccines are three-, four- and eight-valented. The attenuated vaccines include oocytes, emerios with artificially reduced virulence. The use of attenuated vaccines is accompanied with minimal damage of intestinal mucosa of the bird and does not provoke the development of necrotic enteritis.

In accordance with the vaccine guidelines, single-dose immunizations are carried out on mainly clinically healthy chickens aged $1-5$ or 14 days. Immunization is done with spray-method, gel-drip method, with the help of watering or in eyes.

Conclusions: 1. Vaccines for poultry make up $38.7 \%$ of the total number of immune biological medicines in the domestic pharmaceutical market.

2. Vaccines against certain avian diseases make up $73.9 \%$, among them the vast majority - against Newcastle disease $(22.5 \%)$. The share of polyvalent associated vaccines is $26.1 \%$, the bivalent associated vaccines make up $52.4 \%$, namely the Newcastle disease and infectious bronchitis vaccine (17 TN).

3. $85.9 \%$ of vaccines for poultry - foreign production and only $14.1 \%$ - are produced in Ukraine.

4. Vaccines against poultry eimeria at the domestic pharmaceutical market make up 5.6\% and are of foreign origin.

5. The leading type of vaccine against eimeriosis is live attenuated vaccine $-70 \%$.

\section{References:}

1. Berezovs'kyy A.V. (2012). Na rynku protykoktsydiynykh preparativ [On the market of anticoccidic drugs]. Health of animals and medicine, vol. 1 (122), pp. 14-15.

2. Bessonov A.S. (2002). Rezistentnost' k parazitotsidam i puti ee preodoleniya. [Resistance to parasiticides and ways to overcome it]. Veterinary medicine, vol. 7, pp. 24-28.

3. V Ukrayini za 2018 rik poholiv"ya ptytsi zbil'shylos' na 2,9\% [In 2018, the number of poultry increased by 2.9\%]. URL: https://tripoli.land/news/za-2018-rik-pogoliv-ya-ptitsizbilshilosya-na-2-9 (Date of access: 29.01.2019).

4. Kashcheeva M.A. (2017). Immunoprofilaktika eymerioza kur, analiz sovremennykh vaktsin [Immunization maintenance eimeriosis chickens, analysis of the current vaccines]. Proceedings of the Sovremennye problemy obshchey $i$ chastnoy parazitologii: II mezhdunarodnyy parazitologicheskiy simpozium (Russia, St. Petersburg, November 6-8, 2017), St. Petersburg : FGBOU VO SPbGAVM, pp. 126-129.

5. Kashcheeva M.A., Vasilevich F.I. (2018). Obzor vaktsin protiv eymerioza kur, predstavlennykh na rossiyskom rynke [Overview of vaccine against chickens on the Russian market]. Veterinary and feeding, vol. 3, pp. 35-37.

6. Marshalkina T.V. (2014). Metody molekulyarnoyi biotekhnolohiyi spetsyfichnoyi profilaktyky ta diahnostyky eymeriozu u ptakhivnytstvi [Methods of molecular biotechnology for 
specific prophylaxis and diagnosis of eumeriosis in poultry farming]. Scientific Herald of Veterinary Medicine, vol.13 (108), pp. 13-16.

7. Sayt Derzhavnoyi sluzhby z pytan' bezpechnosti kharchovykh produktiv ta zakhystu spozhyvachiv. Spysok zareyestrovanykh veterynarnykh preparativ (veterynarni imunobiolohichni zasoby), 2019. URL: http://www.consumer.gov.ua/ContentPages/Reestri/38/ (Date of access: 01.01.2019).

8. Semenko O.V. (2014). Deyaki osoblyvosti poshyrennya ta zakhodiv borot'by z eymeriozom ptytsi [Some features of the spread and control of poultry eimeriosis]. Veterinary medicine, vol. 8 (141), pp. 7-11.

9. Franchuk-Kryva L.O. (2019). Perspektyvy zastosuvannya fitopreparativ za eymeriozu [Prospects for the use of phytopreparations for eimeriosis]. The young scientist (Veterinary science), vol. 2 (66). URL: http://molodyvcheny.in.ua/ru/archive/66/. 